\title{
Viriloid Women and Bodiless Men: On Modern Sexualities in the Oeuvre of Johannes Semper ${ }^{1}$
}

\author{
MERLIN KIRIKAL
}

\begin{abstract}
This article studies how the profound changes in theorizing human sexualities in the fin-de-siècle and early $20^{\text {th }}$ century were used and re-used in the oeuvre of Estonian cultural moderniser Johannes Semper (1892-1970). In his texts, two modern discourses of sexuality appear in highly telling ways: sexology and psychoanalysis, with which Semper mainly familiarises himself respectively through the works of Otto Weininger and Sigmund Freud. Taking a feminist standpoint to analyse the thoroughly male-centred sexuality discourses of the abovementioned thinkers, this article sets out to study how sexuality and gender are articulated in Semper's oeuvre, both within a heteronormative and queer framework. Two literary texts are closely examined. The first, the short story collection Ellinor (1927), depicts the world entirely through the eyes of an emancipated woman who encounters a lesbian character the first in Estonian literature. This encounter begins the discussion of various desires as the protagonist tries to explain her 'femininity' in contrast to the queer character Madame Liibeon's 'inversion'. The second, Semper's novel Jealousy (1934), is used for comparison, as sexual Bildung and desires are mediated through the eyes of a male heterosexual protagonist.
\end{abstract}

Keywords: Johannes Semper; Estonian literary history; history of sexuality; gender; queer desires

The theoretical understanding of human sexuality underwent important changes in the fin-de-siècle and early $20^{\text {th }}$ century (Schaffner, Weller 2012: 1). Scientists and medical experts enthusiastically scrutinised sexuality: questions of gender and sexual identity and corresponding erotic desires, sexual acts and object-choices, the results of these studies being labelled "sexology" (Marshik, Pease 2019: 56-57). Such treatises defined "normal” sexual conduct and categorised various types of "inverts" - those who felt desire for their

1 Written with the support of EU Regional Development Fund and Education Agency Archimedes. I would like to thank Mirjam Hinrikus, Irina Novikova, Raili Marling, and Tiina Kirss for their valuable input.

DOI: https://doi.org/10.12697/IL.2021.26.2.9 
own sex - drawing a rigid line between hetero- and homosexual individuals (Foucault 2005: 50). In Estonia, the principal mediators of the discourses of sexology were local newspapers (Kalkun 2020), although literary texts and artistic essays also made valuable contributions to interpreting modern sexuality (Bauer 2015: 102). This article therefore discusses aesthetic representations of modern sexualities through a case study, concentrating on how the threads of the 'science' of sexuality are taken in and re-used within both queer and normative frameworks in the texts of the Estonian cultural moderniser, Johannes Semper.

Johannes Semper ${ }^{2}(1892-1970)$ was an early $20^{\text {th }}$ century Estonian writer and a celebrated translator who has been praised for his tireless work in introducing modern cultural currents to the Estonian public. He mainly translated French, Russian, Belgian, Italian and German authors. Well versed in contemporary aesthetics and philosophy, he was among the first in Estonia to introduce Bergson's philosophy, symbolism, futurism and expressionism. These multiple intellectual engagements left a lasting mark on his own aesthetics. Semper's writings are therefore a complex mix of different and even contradictory ideas in vogue at the turn of the $20^{\text {th }}$ century.

What distinguishes Semper from other Estonian cultural modernisers is his easily discernible involvement in discussions of human embodiment and sexuality, and related questions of gender. His texts belong to the reconceptualisations of gender relations accompanying the advent of feminist discourse. In Estonia, feminism began to take shape in the second half of the $19^{\text {th }}$ century when women's demands for education grew stronger, then gained increased social attention in the first decade of the $20^{\text {th }}$ century when attention shifted towards women's civil rights (Annuk 2013: 95). This article examines Semper's take on the emancipation of women, analyzing how and why his representations of sexualities developed. Indeed, at least two modern discourses of sexuality appear in suggestive ways in Semper's oeuvre. The first, sexology, is represented by one of the most widely known works of the field at the beginning of the $20^{\text {th }}$ century, Otto Weininger's treatise Geschlecht und Charakter ('Sex and Character', 1903). Secondly, Semper was drawn to psychoanalysis, which he found to have formidable explanatory power, although the line between sexology and psychoanalysis is often blurred (Steuer 2005: xvii).

Inserting Semper's work into a global arena re-works the already thoroughly investigated spaces of Western sexology and its engagements with privileged cultural representations (i.e. sexually explicit texts of literary decadence and

2 For further information, see Talviste 2007. 
modernism) and offers stimulating aesthetic examples of gender ${ }^{3}$ differences. This allows us to explore the frameworks and the transcultural channels through which the elements of sexuality manifest themselves in Semper's oeuvre.

\section{The Intellectual Context of Semper's Approach to Sexuality}

As a culturally sensitive author, Johannes Semper was among numerous thinkers who verbalised the modern fixation with sexuality, both the same-sex inclinations and heterosexuality, although his texts also manifest the masculinised yearning to theorise sexual desire. His idiosyncratic approach to these issues is a contradictory amalgam of his readings and conversations with peers, rather than a coherent theory. The first stimulus for discussing this topic probably came from the Viennese philosopher Otto Weininger (1880-1903). His capacious Geschlecht und Charakter, which was widely read in Europe, set out "to analyze the differences between male and female from all perspectives - biological, cultural, metaphysical - and to base a thoroughgoing critique of modern civilization on that analysis" (Sengoopta 2000: 4).

Estonian intellectuals read Weininger in the original German, but it is also likely that he was read in Russian, which was widely spoken among local intelligentsia. ${ }^{4}$ The first complete Russian translation of Geschlecht und Charakter appeared in 1908, preceded by excerpts published in 1903 (Bershtein 2012: 212). ${ }^{5}$ Russian intelligentsia were more interested in Weininger's ideas about "sexual intermediacy", according to which all humans were partly male and partly female, i.e. simultaneously in possession of male and female attributes (Matich 2005: 209, 245).

Weininger was by no means alone in his interest in sexual intermediacy, which was hotly discussed during the fin-de-siecle and at the beginning of the

3 Although I subscribe to the contemporary feminist idea that the distinction between sex as biological and gender as cultural is theoretically unproductive, to avoid confusion I will use the notion 'gender' when discussing cultural representations of women and men.

4 At the beginning of the $20^{\text {th }}$ century Estonia was still legally part of the Russian empire with Baltic Germans as the de facto power. The language of instruction was therefore either Russian or German.

5 Weininger's text was obligatory reading for every educated Russian. The publication of the full translation also shows his reputation outside of German-speaking cultures (Bershtein 2012: 212). His book also caught the attention of Latvian intelligentsia (Cimdina 2000: 92, 95-96), although in Finland gender differences were arguably discussed instead from a Nietzschean perspective (Huusko 2019: 78). 
$20^{\text {th }}$ century. The pioneering thinker, Karl Heinrich Ulrichs, conceptualised it in a Cartesian framework as a misfit between one's soul and body (Bauer 2015: 103). Ulrichs argued in the 1860s that a man who desires another man has a female soul inside his body (ibid.). Naming these men in Plato's footsteps Uranians, ${ }^{6}$ he also introduced the term Dionian love to mark same-sex desire between women, although due to his personal agenda he devoted himself to the research of Uranian desire (ibid. 104). Ulrichs (1994: 35) considered "manmanly love" physiologically as a germ that is latent until puberty but already implanted in the male body ab ovo (Bristow 1997: 21).

Opposed to the binary theory of Uranian desire, a theory of in-betweenness was proposed. The sexologist Richard von Krafft-Ebing, who is considered an influence on Sigmund Freud and whose lectures Weininger attended (ibid. 25), argued that homosexuality originated from bisexuality, which he understood as the human being's earliest embryonic disposition (van Haute, Westerink 2016: xxiii). This resembles Weininger's stance in the first, positivist part $^{7}$ of his Geschlecht und Charakter, and although he contradicted the idea in later sections, it is still considered to be one of its founding biological presuppositions (Sengoopta 2000: 9). Conceptualising organisms as bisexual from scratch, Weininger (2005: 12) reckoned that gender is a matter of degree, i.e. it depends on how much of a certain sexed "substance" one happens to have. This biologist's stance comes in handy to Semper who ultimately leans toward a biologically deterministic viewpoint, although this is masterfully hidden under more emancipatory ideas.

In Estonia, Weininger was often (in)directly quoted in personal notebooks (i.e. the prominent novelist A. H. Tammsaare's quotes in his personal notes) and private correspondence (i.e. the letters between Friedebert Tuglas and Johannes Aavik), mainly to bolster their belief in women's moral and intellectual inferiority, but also to oppose Weininger's ambitious theory (Hinrikus 2015: 173; Vihma 1990: 28). Semper's reading of Weininger is more versatile. In addition to the Woman Question, he was also interested in bisexuality and homosexual desire - curiously more in woman-womanly than man-manly love.

6 The other word in use was Karl Maria Kertenby's (alias Karoly Benkert) term "homosexuality", coined in 1869 (Bristow 1997: 179).

7 Weininger's interdisciplinary treatise has two parts (Sengoopta 2000: 4). The first positivist part "was the result of the need to consider the general biological validity of the principles" of gender difference (Weininger 2005: 69). In the second introspective part however, Weininger is convinced that a human "must necessarily be either male or female" (ibid.). One can only speculate about which parts of the book were more familiar to Semper. 
KIRIKAL

During his school years in Pärnu (1905-1910), Semper wrote a presentation on Geschlecht und Charakter (Semper 1978: 114), although it is unclear which threads of Weininger's massive treatise he focused on, as young Semper text's is nowhere to be found. Retrospectively, he claims that he knew Weininger's work well, enabling him to notice contemporary so-called plagiarisms of Weininger in Estonian culture. ${ }^{8}$ For example, Semper's and his alter egos' ideas about women's incapacity to enjoy art abstractly (Semper 1918: 20) and the definition of women only by their sexuality (Semper 2013: 201) largely coincide with Weininger's opus. The outcome of Semper's reading of Weininger, and later of Freud, was finding support for constructing - his ideal of (semi-)emancipated femininity. Those ideas helped him in drawing a boundary between desirable masculine femininities that do not cross the line of heterosexuality and "weird" emancipated, sometimes hyper-masculine femininities which Semper considered undesirable and ridiculous (ibid.34).

What differentiates Weininger's and Freud's viewpoints - both far from easily legible - is firstly that Weininger did not see "mature" homosexuality as a result of disturbed development the way Freud did (Sengoopta 2000: 10).9 Secondly, Weininger eventually wanted to mould the situation to his idealistic point of view, while Freud confidently claimed to be describing data he collected from his cases. In Estonia the 1930s mark the conscious reception of Freudianism (Undusk 1988: 378). Semper engaged with psychoanalysis during his studies in Berlin (1921-1925) with the impetus to study Freud coming from Max Dessoir's lectures on parapsychology and psychoanalysis. (Siirak 1969: 88-89)

Impressed by psychoanalysis, Semper wrote an essay on the Estonian national epic, "Kalevipoja" rahvaluule-motiivide analüüs (Analysis of Folkloric Motifs in "The Son of Kalev", 1924). Here we come across at least two psychoanalytical interpretations of sexuality that greatly influenced his aesthetics: firstly, the division between lust and prohibition taught in early childhood by caregivers, and secondly the indisputable affectionate bond between mothers and sons, and fathers and daughters. This heterosexual link is unquestionably

8 Accusations of copying other writers was a trend in Estonia, especially when Gustav Suits earned a professorship at the University of Tartu in 1921 and disseminated his historical-comparative method that aimed to disentangle the nodes of influences in literature (Peep 1991: 145). Semper was accused of plagiarising P. Morand, J. Giraudoux and J. Delteil (Siirak 1969: 105).

9 An important theoriser of homosexuality was Magnus Hirschfeld, whose lectures Semper attended in 1929 (Semper 1929: 724). 
based on gender difference and on children's 'natural' instincts. Semper avers that it is an axiom that needs no further proof (Semper 1924: 14, 19, 20).

From a feminist perspective such ideas are highly problematic and Freudian psychoanalysis (and also, implicitly, Weininger's theory) has been criticised by feminist scholars. Luce Irigaray (1985: 34-54) points out that Freud's emphasis only seemingly lies on universal human sexuality: his ideas are male-centred, thus useless in disentangling female sexuality. Moreover, strong urges are always seen as male in essence (Freud 2016: 71; Irigaray 1985: 35). There are two other pitfalls in Freud's theories. Firstly, Freud admits that, compared to a boy's, the beginnings of the sexual life of a girl are obscure, but he does not make an effort to dig into the cultural prejudices underneath the origins of how girls' sexuality is depicted as shady (Freud 2016: 61; Irigaray 1985: 25). The result is Western culture's inclination to represent heterosexual male desire (though not necessarily in an embodied manner) and the abundant sexual objects that arouse it, including women, while we know little about women's desire (ibid. 23). This lack was reproduced in the blossoming discourses of sexuality at the beginning of the $20^{\text {th }}$ century that informed Semper's creative quests.

\section{Constructing an Authentic Gendered Self}

Two fictional texts in Semper's oeuvre can be especially fruitfully read through the lenses of sexology and psychoanalysis: the collection of five short stories entitled Ellinor (1927) and the novel Armukadedus ('Jealousy', 1934). The viewpoint of the heterosexual first-person narrator, represented with discernible sympathy, is similarly employed to explore the emotional challenges of growing up and the complex personal dilemmas of developing intimate relationships. These books explicitly treat the problems faced by a young, white, middle-class woman and man as they leave 'naïve' thoughts of adolescence behind in order to gain intellectual maturity and autonomy, one proof of which is heterosexual relationships.

Ellinor is narrated by a vigorous and assertive New Woman ${ }^{10}$, a schoolteacher described as "extremely eccentric" by the reviewer Marta Sillaots (1928), implying that the protagonist is far from embodying mainstream gender norms. This particular narrative framing was a radical event in Estonian cultural history, as this was the first time a male author had published a text

10 New Woman is a term denoting modern fictional or real feminist women who strove for equality between the sexes, subverted restrictive stereotypes and advocated an active lifestyle (Ledger 1997: 10, 181). 
mediated entirely through the eyes and the 'I' of a woman (cf. Kirikal 2017). This intriguing, gender troubling choice is illustrated more colourfully by the contrast with representation of a male character, the lawyer Enn Maiste from Jealousy. Both narrators are looking back on crucial moments in their life, Enn on one specific event and Ellinor on multiple events. Their journeys and identities are thus retrospective.

Through detailed observations, both Ellinor and Enn try to access something they perceive as authentic and essential. Assumptions, lies, distortions, pretensions are described as cheap and fragmented (Semper 1934: 5-12). Furthermore, the required truthfulness is at least partly sexualised. Ellinor claims that it is necessary to get "closer to life", and this "breaking into life" takes place when she suddenly feels desire for a stranger on the train (Semper 1927: 9, 14). Desiring someone on a moving train is also a motif in one of Semper's poems, where the lyrical 'I' is supposedly male (Semper 1917: 43).

Indeed, certain erotic, emotional and embodied topics are represented either via a male point of view in poetry or via a female point of view in prose. In contrast, Semper's male prose characters - as opposed to his continually feminised lyrical poetry - never get the chance to show explicit desires which are rigidly coded 'feminine'. However, not only does corporeal experience of desire point towards authentic being, but the analysis of that desire is also necessary. Following Foucault (2005: 41, 6), both Ellinor and Enn need to confess their sexual being in detail. Their raison d'être is therefore the combination of a certain experience - different for the male and the female characters - and the analysis of this desire. These characters indulge in pleasures, although the limits of representation for these blisses are discernibly more rigid for male characters, as demonstrated below.

In order to ease the lurking inauthenticity, the characters must get rid of confining social norms. Ellinor is sceptical towards her teachers, schoolbooks and the grandmother she sees in her dreams. Enn feels reluctance toward religion and the media, which proclaim false truths. However, the obstacle in his journey towards the sexual-analytic truth is the harshness of the sexual education offered by his parents (Semper 1934: 151). In his essay on Kalevipoeg (1924: 18-19), Semper praised Freud for shifting attention towards infantile manifestations of sexuality, concluding that children learn to draw a rigid border between the allowed and the forbidden. This is especially relevant for Enn, who describes his sexual Bildung through genital heterosexual encounters at the age of six with the daughter of his landlord (Semper 1934: 151). There are no references to the childhood same-sex affections that Weininger (2005: 44) sees as very common and associates with bisexual tendencies in all human beings. Enn's memories are rigidly sexually differentiated and also full of 
shame due to the embodied restrictions set by his family and the binary valuesystems he created as a boy. Jealousy's plot implies that this segment of Enn's childhood is the cause of his later association of sexual acts with the feeling of disgust. This further points to a Freudian understanding of sexuality as "intrinsically conflictual": experiences of guilt are inscribed on sex by social circumstances (van Haute, et al. 2016: xx). Curiously, Ellinor is not vocal about her early childhood memories, focusing instead on her explorations in puberty, emphasizing that as a schoolgirl she constantly strove to break the norms. Enn's sexual development as a boy is verbalised, while Ellinor's sexual development as a girl remains fuzzy.

There are further differences between Enn and Ellinor's journeys towards sexual pleasure and personal autonomy. The first discrepancy is that longings for authenticity are notably more embodied and naturalised in Ellinor. Although she is a city girl - an educated schoolteacher who enjoys an active lifestyle -, she also knows animals, plants and the daily rhythms in villages. Hence, she is more in touch with her 'natural' roots, whereas Enn's connections with country life are (intentionally) blurred. Ellinor's wildness is further emphasized by her nudist tendencies. She finds social norms such as tight clothes annoying, as opposed to the freedom of nudity. (Semper 1927: 9, 13). In contrast, Enn feels ridiculous without the outer crust when he is finally forced to take off his clothes before his first intercourse. Whilst the naked female body is a symbol of freedom and reaction against social norms, a positively marked naked male body does not exist in Semper's oeuvre.

We might propose that Ellinor, an energetic and strong woman, is a symbol of Semper's emancipatory gender politics. As a New Woman she extends the boundaries of representation, whereas Enn closes them off. Employing the literary New Woman thus opened up aesthetic possibilities (Witt-Brattström 2004: ix, xiii): Semper was experimenting with something he saw as forbidden to male protagonists. The chance to inscribe - with the hand of a white heterosexual man - the 'I' of the woman gave Semper more flexibility and freedom. This is a paradox, as women even in the 1920s and 1930s did not have the same symbolic and social rights in Estonia, while men were objectively freer. ${ }^{11}$ However, a modern woman could undress to go swimming and be the explicit object of homosexual desire without the feeling of shame. Thus, the

11 Estonian women could formally attend lectures in 1915, while the right to vote was achieved in 1917, which did not mean that women were automatically perceived as active policymakers. Even though men and women were equal in terms of civil and political rights, economic rights, social and sexual norms were still restrictive (Kivimaa 2009: 70-71). 
KIRIKAL

second discrepancy between the figures of Enn and Ellinor is that such carefree possibilities of desire were not available for Semper's fictional male heroes. Semper stepped into gender fluidity to embody forbidden pleasures allowed to New Women. Ellinor's body (her menstruation and urges) is more abundantly worded than Enn's bodily feelings, she even describes herself as plural (Semper 1927: 10, 12), which is Irigarayan avant-la-lettre. Ellinor avers with pleasure, "There was a lot of me, and it was frightening, I could not keep myself together" (ibid. 12). ${ }^{12}$ While Semper is doing something innovative, i.e. depicting female desire, these textual strategies might instead be underlining the Weiningerian belief that woman "is sexuality itself" (Weininger 2005: 173). Considering the historical context, both conclusions are possible, but unlike his fellow Estonian writers, Semper's ideas have a feminist undertone.

Thirdly, Enn and Ellinor are different in that Ellinor embodies her life literally. Despite what her teachers said, Ellinor is convinced that human development can take place in leaps (ibid. 11). She tests the shady ground between language and reality and embodies her beliefs, differentiating herself from Enn, who repeats the fact that truth is ungraspable. From theorising about jumping as a form of development, Ellinor builds a bridge to physical jumping; in order to follow the man with whom she fell in love, she jumps out of a moving train. Ellinor's yearning to leap towards other stages of life has its broader intellectual context in alternative Darwinist theories, such as that of the Dutch botanist Hugo De Vries. While Charles Darwin assumed that evolution and the emergence of new species was a gradual process, De Vries proposed a theory of sudden and large mutational change (Levit, et al. 2008: 78). In his opinion, new species arose only by means of sudden and directly observable saltations (ibid.). Ellinor's physically strenuous jumping practices (out of a moving train, high jump and long jump skills) imply that the existential goals she has set for herself also have to be achieved immediately on a physical level. Thus, she is a proponent of rapid cultural, physical, sexual personal development. But in order to sustain her extremely dynamic moving and loving practices, she must make sure that she will not run out of energy.

Energy was a thoroughly gendered term during the fin-de-siècle and first part of the $20^{\text {th }}$ century. Male energy and energy's maleness is relevant in Freudian understandings of libido (Freud 2016: 71). In this framework, a woman manifesting sexual desire towards somebody is seen as an invert,

12 "Mind oli nii ehmatavalt palju, et ma kõike ei suutnud enam koos hoida" (author's translation). 
a viriloid woman (Beauvoir 1989: 39). ${ }^{13}$ The common timebound belief was that sexual activities are strenuous and masculine. Energetic Ellinor - a jumping aficionado - is therefore a viriloid woman, not in conformity with the prevailing gender norms. What is curious is that Ellinor is represented in an inspiring manner, perhaps because certain types of masculinity performed by women were considered desirable and sexually attainable for the male gaze.

Thus, Ellinor represents one type of masculine femininity. The other type is Madame Liibeon, who as a lesbian is shown from Ellinor's viewpoint as viriloid in a 'degenerate' sense. This stance subverts the narrator's seemingly liberal position towards fluid gender identities. Ellinor's body is represented as positive, while Liibeon's masculine body poses a problem.

\section{The Fear of the Organic Lesbian}

Semper's texts and characters are far from indifferent towards the heated debate on same-sex desire in his time. The lesbian character Madame Liibeon from Ellinor, Semper's explicitly queer character, is the most evocative literary representation of lesbianism in Estonian culture in the 1920s. Madame Liibeon is the owner of a country manor and a self-declared hostess for aspiring female artists. Ellinor's friend is staying at the mansion and they invite Ellinor to join them. Ellinor travels there, and to her astonishment discovers that her hostess is a viriloid woman par excellence. What intellectual resources does the narrator draw upon whilst explaining Liibeon's 'inversion'?

Ellinor partly employs the binary understanding of homosexual desire. Before arriving at the mansion, she already has premonitions. She carries out a graphological analysis of Madame's letter and, on the basis of the handwriting, assumes that Liibeon has strong muscles, a certain aggressiveness, but also an inclination to depression (Semper 1927: 58-59). It appears to Ellinor that Madame is de jure a woman but de facto a man, which corresponds to Ulrichs' dualist theory of inversion. Liibeon's lesbianism is also conveyed through the body - strong manly muscles pressing against the paper whilst writing consistent with Weininger's (2005: 41) claim that "... a sexual invert always shows an anatomical approximation to the opposite sex."

But Ellinor is only briefly satisfied with this binary explication and soon starts to undermine it, noticing that Liibeon's way of stylising the body has characteristics of both genders: for example, $s($ he) wears long boots and a

13 In contrast, Weininger (2005: 173) advocated the exact opposite: in his understanding women represented mere sexuality, being incapable of concentrating on anything other than sex. 
kepi but at the same time a grey home-sewn dress (Semper 1927: 61). This observation changes Ellinor's theory of lesbianism: "Sad that nature while creating her remained in-between in deciding which gender should be made prevalent in this human being: thus, whilst the creator was doubting, the human being had already been molded as woman." (ibid. 73-74) (14 $^{14}$ llinor does not emphasize Liibeon's binary 'confusion', but rather explicates Madame's socalled nature as something intermediate.

Weininger's and Freud's theories highlight Liibeon's lesbianism as an in-between state (ibid.). Ellinor claims that there are no clear-cut divisions between the masculine and feminine sides of Liibeon. Rather, $s($ he) is crammed with contrasts impossible to rigorously divide into two categories. $\mathrm{S}($ he) is, similarly to Ellinor herself, multiple (ibid. 79). This is not disgusting for Ellinor; quite the contrary, it is interesting to observe, as this experience forms part of Ellinor's heterosexual confession (ibid.). Still, it is crucial to point out that although Ellinor tries to understand Liibeon, she retains an ironic viewpoint, coaxing the reader into thinking that Liibeon's desire is not to be taken seriously. This stance dominates, even when Ellinor's overall thinking about Liibeon's gender is inconsistent and changing, underlining that literary texts step into social discussions in complex ways. Ellinor eventually concludes that Liibeon's heart contains two types of blood (ibid. 81). Hence lesbian desire is theorised as anatomical (blood-related) and inevitable. These reflections lead Ellinor to conclude that in Liibeon's presence her own "shoots" (Est. idud) of femininity gather strength against the buds of masculinity (ibid. 79).

This usage of organic systems to articulate highly complex matters has roots in Western patriarchal metaphysics and the positivist mindset prevailing in Semper's time. Since the $18^{\text {th }}$ century, biology had been regarded as the most scientific (verifiable, objective) of all sciences and thus biological explications were applied to add weight to certain scenes (Fairer 2009: 16). Organic modes of thinking were morally loaded: the vocabulary employed to signify the "good, valuable, truthful and beautiful" (from human virtues up to market relations) in Western cultures was often hitched to nature and/or biology (Taussig 1977: 141). The explanation of non-conformist sexual desires follows a similar logic: botany and anatomy are applied as a means of explicating something conclusively. Ellinor naturalises Liibeon's gender by using this exact technique. Madame's desire seeps out from nature (blood); her own femininity is caused by something fermenting in her body (shoots). This also implies that Semper's

14 "Kahju, et loodus teda luues oli kahevahele jäänd, kumba sugu ses inimeses valdavaks teha: nõnda, looja kaheldes, oli inimene ise juba naiseks vormunud.“ 
albeit thick layer of emancipatory thinking still derives from a biologically determined root (cf. Kirikal 2020).

Throughout the story Liibeon embodies values typical of Western masculinity. The apotheosis of this occurs in a scene in the empty cemetery where Liibeon tries to wrestle with Ellinor. Liibeon is actually not a wrestling aficionado but invites Ellinor to make love. The location of the sexual encounter, the desolate graveyard, is symbolic, as Ellinor suggests that graves correspond with beds and men tend to experience a creative-fertile urge in places like these. In Semper's oeuvre masculine sexual overtures are without exception associated with aggression, violence, even death, and often involve devouring or biting the victim. This accords with Freud's understanding that the sexuality of most men contains an element of aggression, an inclination to overpower (Freud 2016: 20). In a similar vein, Liibeon, barbarised by desire, bends Ellinor to the ground and kisses her neck. Ellinor's resistance turns Liibeon on even more, and thus Ellinor presumes that maybe "the other blood" has broken free in Madame's veins (Semper 1927: 81). Liibeon's technique of foreplay is deliberately aggressively masculine: $s($ he) is excited when resisted and wants to be on top during "the match".

An important aspect of Ellinor's own narrative of sexual encounters unfolds here, and something similar happens in the next short story. A shy German poet and war veteran, who is unanalytical and out of shape in the protagonist's opinion, falls in love with Ellinor. She is not fond of him but rather amused. Eventually he makes a sexual advance. He approaches Ellinor, raises his "unclear" eyes, grasps both of her hands and starts kissing then biting her (ibid. 119). She kicks him off and escapes. Ellinor therefore faces two sexual attacks from someone she knows and trusts, one from a feminine man and the other from a masculine woman. Interestingly, they do not bother her at all. In contrast, Enn's lover in Jealousy, Krista, tells a similar story, psychologically more convincing than Ellinor's because Krista seems to be disturbed by the memory. ${ }^{15}$ She confesses to Enn in an intimate setting that during a past trip to a sanatorium in Yalta, a young man with crazy eyes was about to rape her in a secluded place. Hence, several female characters in Semper's oeuvre experience some sort of sexual violence.

15 A military officer also attempts to rape her in an earlier story (Semper 1927: 40) but this attack is different as the other characters who force themselves on Ellinor are from her inner circle. It is still curious that Ellinor is not affected by this officer's rape attempt, and psychologically these stories are rather unconvincing. Could this be the gap where the implicit author's male 'I' is exposed? 
KIRIKAL

These characters are embedded in a heteronormative matrix, but the only story of sexual violence that triggers an emphatic response is when a woman is attacked by a masculine man and also confesses it coherently to another potentially dangerous masculine man. Some narratives of desire are therefore depicted as authentic and possibly unsafe; others as mere jokes, functioning as common narratives of 'foreplay' mediated through the eyes of fictional women. It seems that for heterosexual female characters, Eros is not exactly emancipating, but instead unpredictable and dangerous. This paints an ominous picture of female sexual encounters that have been totally overlooked in Estonian literary history.

\section{Conclusion}

This article analysed how sexuality and gender - fervently discussed issues in the first half of the $20^{\text {th }}$ century - were talked and thought about in Estonian culture, using examples from the oeuvre of Johannes Semper. In his interpretation of hetero- and homosexual development, Semper employs modern theories of sexuality, including those of Otto Weininger and Sigmund Freud. Both he as implicit author and his characters take heterosexual eroticism as axiomatic. Various examples insinuate that Semper's texts function on rigidly binary systems: for example he genders genres (poetry as feminine and prose as masculine). However, he remains increasingly curious about the cultural meanings and possible 'roots' of queer desires. The comparison of two first-person heterosexual protagonists reveals that the female character Ellinor is discernibly more embodied and sexually expressive than her masculine counterpart Enn, who struggles with shame concerning all aspects of his body. This explains why Semper chose a female first-person protagonist for his collection Ellinor, since this broadened the limits of gendered representation. He could experiment aesthetically and try out modes disallowed in binary and heteronormative contexts for male characters. Ellinor also represented a masculine woman, Madame Liibeon, the first evocative literary representation of lesbianism in Estonian culture. The protagonist observes Liibeon in detail and theorises lesbianism, firstly in a binary frame as a male desire inside a woman's body. After testing the bisexual model, Ellinor eventually argues that homosexuality emerges when 'nature' cannot decide whether to choose the male or female constitution. Ellinor inserts the cause of same-sex desire into blood, making it biologically unsurpassable. The story collection also shows that there might be a scent of (sexist) determinism underneath Semper's ostensible liberalism: in representations of masculine desire, violence becomes an unavoidable attribute that is nevertheless treated with an unconvincingly carefree attitude by 
Semper's female alter ego. Semper's texts therefore offer dense exemplary material for those interested in debates over changing gender relations and sexological issues, as well as in the overlappings between liberating and restricting ideas about gender and sexuality.

\author{
Merlin Kirikal \\ merlinkirikal@gmail.com \\ Tallinna Ülikool / Tallinn University \\ ESTONIA
}

\title{
Works cited
}

Annuk, E. 2013. Emancipation and the New Woman in Early Estonian Journalism. - Ideas in History. Journal of the Nordic Society for the History of Ideas, 7, 95120.

Bauer, H. 2015. Literary Sexualities. - D. Hillmann, U. Maude, eds., The Cambridge Companion to the Body in Literature. New York: Cambridge University Press, 101115. https://doi.org/10.1017/CCO9781107256668.008

Beauvoir, S. de 1989. The Second Sex. - Trans. H. M. Parshley. New York: Vintage Books.

Bershtein, E. 2012. The Notion of Universal Bisexuality in Russian Religious Philosophy. - R. Alapuro, A. Mustajoki, P. Pesonen, eds., Understanding Russianness. London, New York: Routledge, 210-231.

Bristow, J. 1997. Sexuality. London and New York: Routledge.

Cimdina, A. 2000. Feminisms un literatura. - A. Cimdina, ed., Teksts un klatbutne. Riga: Jumava, 62-99.

Fairer, D. 2009. Organising Poetry. The Coleridge Circle, 1790-1798. Oxford: Oxford University Press.

Foucault, M. 2005. Seksuaalsuse ajalugu I. Teadmistahe. - Trans. I. Koff. Tallinn: Valgus.

Freud, S. 2016. Three Essays on the Theory of Sexuality. The 1905 Edition. Trans. U. Kistner. P. van Haute, H. Westerink, eds., London, New York: Verso.

Hinrikus, M. 2015. Tammsaare's Constructions of Femininity in Light of Weininger's Concept of Sex Difference. - Journal of Baltic Studies, 46 (2), 171-197. https://doi. org/10.1080/01629778.2014.981672

Huusko, T. 2019. Naisesus, iseseisvus ja etniline natsionalism. Soorollidest Soomes ja Eestis maailmasõdade vahel. - A. Allas, T. Abel, eds., Eneseloomine. Emantsipeeruv naine Eesti ja Soome kunstis. Tallinn: Eesti Kunstimuuseum, 76-85.

Irigaray, L. 1985. The Sex Which Is Not One. Trans. C. Porter, C. Burke. Ithaca, New York: Cornell University Press. 
KIRIKAL

Kalkun, A. 2020. Homoseksuaalsuse sõnastamise katsed. Eulenburgi skandaal ja Magnus Hirschfeld XX sajandi alguse Eesti ajakirjanduses. - Keel ja Kirjandus, $1-2,112-132$.

Kirikal, M. 2017. Sportlanna keha ja hing Johannes Semperi „Ellinoris” (1927). - Keel ja Kirjandus, 7, 417-433.

Kirikal, M. 2020. Tervikupüüe ja fragmendihirm Johannes Semperi loomingus. - Keel ja Kirjandus, 3, 211-229.

Kivimaa, K. 2009. Rahvuslik ja modernne naiselikkus eesti kunstis 1850-2000. TallinnTartu: Tartu Ülikooli Kirjastus.

Ledger, S. 1997. The New Woman: Fiction and feminism at the fin de siècle. Manchester, New York: Manchester University Press.

Levit. G. S., Meister, K., Hoßfeld, U. 2008. Alternative Evolutionary Theories: A Historical Survey. - Journal of Bioeconomics, 10 (1), 71-96. https://doi.org/ 10.1007/s10818-008-9032-y

Marshik, C.; Pease, A. 2019. Modernism, Sex, and Gender. London, New York: Bloomsbury.

Matich, O. 2005. Erotic Utopia. The Decadent Imagination in Russia's Fin de siècle. Madison: The University of Wisconsin Press.

Peep, H. 1991. Gustav Suits ex cathedra. - Keel ja Kirjandus, 3, 138-147.

Schaffner, A. K.; Weller, S. 2012. Introduction. - A. K. Schaffner, S. Weller, eds., Modernist Eroticisms. European Literature after Sexology. Houndmills, Basingstoke, Hampshire: Palgrave Macmillan, 1-22.https://doi.org/10.1057/9781137030306_1

Semper, J. 1917. Pierrot. Tallinn: Siuru.

Semper, J. 1918. Hiina kett. Tartu: Odamees.

Semper, J. 1924. Kalevipoja rahvaluulemotiivide analüüs. Tallinn: Loodus.

Semper, J. 1927. Ellinor. Tartu: Loodus.

Semper, J. 1929. Muljeid PEN-klubide rahvusvahelisest kongressist Viinis. - Looming, 6, 721-736.

Semper, J. 1934. Armukadedus. Tartu: Loodus.

Semper, J. 1978. Mälestused. Tallinn: Eesti Raamat.

Semper, J. 2013. Päevaraamatud. Tartu: Ilmamaa.

Sengoopta, C. 2000. Otto Weininger, Sex, Science, and Selfin Imperial Vienna. Chicago: University of Chicago Press.

Sillaots, M. 1928. Johannes Semper: Ellinor. Novellid. - Eesti Kirjandus, 1, 50-51.

Siirak, E. 1969. Johannes Semper. Tallinn: Eesti Raamat.

Steuer, D. 2005. A Book That Won't Go Away. Otto Weininger's Sex and Character. D. Steuer, L. Marcus, eds., Sex and Character. An Investigation of Fundamental Principles. Bloomington and Indianapolis: Bloomington University Press, xi-xlvi.

Talviste, K. 2007. On the Way towards Modernity: an Estonian Poet's Relationship with the City. - Interlitteraria, 12, 361-370.

Taussig, M. 1977. The Genesis of Capitalism amongst a South American Peasantry: Devil's Labor and the Baptism of Money. - Comparative Studies in Society and History, 19 (2), 130-155. https://doi.org/10.1017/S0010417500008586 
Viriloid Women and Bodiless Men

Ulrichs, K. H. 1994. The Riddle of Man-Manly Love: The Pioneering Work on Male Homosexuality. Trans. M. A. Lombardi-Nash. New York: Prometheus Books.

Undusk, J. 1988. Nende ja meie Austria. - Keel ja Kirjandus, 6, 374-379.

Van Haute, P., Westerink, H. 2016. Introduction: Hysteria, Sexuality, and the Deconstruction of Normativity. - P. van Haute, H. Westerink, eds., Sigmund Freud. Three Essays on the Theory of Sexuality. The 1905 Edition. London, New York: Verso, xiii-lxxvi. https://doi.org/10.4324/9781315312255

Vihma, H. 1990. Kultuurilugu kirjapeeglis. Johannes Aaviku ja Friedebert Tuglase kirjavahetus. Tallinn: Valgus.

Weininger, O. 2005. Sex and Character. An Investigation of Fundamental Principles. Trans. L. Löb. D. Steuer, L. Marcus, eds., Bloomington and Indianapolis: Bloomington University Press.

Witt-Brattström, E. 2004. Preface. - E. Witt-Brattström, ed. The New Woman and the Aesthetic Opening: Unlocking Gender in Twentieth-Century Texts. Stockholm: Södertörns högskola, vii-xiv. 